\title{
The Influence of Social Media Use and Parenting Style on Teenagers' Academic Motivation and Academic Achievement
}

\author{
Kinanti Prabandari* \\ Department of Family and Consumer Sciences, \\ Faculty of Human Ecology, \\ Bogor Agricultural University
}

\author{
Lilik Noor Yuliati \\ Department of Family and Consumer Sciences, \\ Faculty of Human Ecology, \\ Bogor Agricultural University
}

*Corresponding author: kinanti.ipb@gmail.com

\begin{abstract}
This study aimed to analyze the effects of social media use and parenting styles on teenagers' academic motivation and academic achievement. The population was grade 11 students of four schools; two schools in Bogor Regency (representative of rural area) and Bogor City (representative of urban area). Samples were 120 students taken by using proportional random sampling. The results showed that the social media use in urban area was higher than that in rural area. Most parents in both regions implemented authoritative parenting style. Intrinsic academic motivation was influenced by authoritative and permissive parenting styles, and duration of social media use. Extrinsic academic motivation was influenced by authoritarian and authoritative parenting styles, and duration of social media use. Teenagers in urban area had better academic achievement than those in rural area, as well as teenage girls compared to teenage boys. Meanwhile, authoritarian parenting style was proved to lower teenagers' academic achievement.
\end{abstract}

Keywords: academic achievement, academic motivation, parenting style, social media

\begin{abstract}
Abstrak. Penelitian ini bertujuan untuk menganalisis pengaruh penggunaan media sosial dan gaya pengasuhan orang tua terhadap motivasi belajar dan prestasi belajar remaja. Populasi dalam penelitian ini adalah siswa kelas XI di empat sekolah; masing-masing dua sekolah di Kabupaten Bogor (mewakili wilayah perdesaan) dan Kota Bogor (mewakili wilayah perkotaan). Contoh diambil menggunakan metode proportional random sampling sebanyak 120 siswa. Hasil penelitian menunjukkan penggunaan media sosial remaja di kota lebih tinggi dibandingkan dengan remaja di kabupaten. Sebagian besar orangtua remaja di kedua wilayah menerapkan gaya pengasuhan otoritatif. Motivasi instrinsik dipengaruhi oleh gaya pengasuhan otoritatif dan permisif, serta durasi penggunaan media sosial. Motivasi ekstrinsik dipengaruhi oleh gaya pengasuhan otoritatif dan otoritarian, serta durasi penggunaan media sosial. Remaja di perkotaan mencapai prestasi akademik yang lebih baik dibandingkan remaja di perdesaan, begitu pula dengan remaja perempuan dibandingkan remaja laki-laki. Sementara itu, gaya pengasuhan otoritarian terbukti menurunkan prestasi akademik remaja.
\end{abstract}

Kata kunci: gaya pengasuhan, media sosial, motivasi belajar, prestasi belajar, remaja 


\section{Introduction}

Nowadays, the science and technology are developed more rapidly which also influence the development of information and communication. One form of communication with the combination of current technology development is the advent of the Internet. The Internet provides a variety of services that can be utilized easily by users. One of the most desirable communities is social media. Social media is a social structure made up of nodes (which are generally individuals or organizations) which is woven with one or more specific types of relationships such as values, visions, ideas, friends, descent, and others. The examples of social media are Facebook, Twitter, Instagram, Path, and others. The existence of a social media allows users to interact with people from all over the world at a lower cost.

User of social media in Indonesia is increasing due to easier access to the Internet. Based on the Ministry of Communications and Information Technology (2014), the total Internet users reach 63 million people and as many as 95 percents use the Internet to access social media. Until now, Internet users in Indonesia have reached 82 million people, and 80 percent of them are teenagers aged 15-19 years old. It posits Indonesia in eighth ranked in the world, and Indonesian Facebook users is ranked fourth of the world (Ministry of Communications and Information Technology, 2014). In 2011, Facebook users in Indonesia were once the highest rate up to number two in the world under the United States. Meanwhile, Twitter users in Indonesia rank fifth highest in the world, with 19.5 million users.

Social media use, especially Facebook, among children and teenagers is considered high although the trend was declined. About 25 percent of Facebook users age 13-17 have left this platform in the last 3 years (Saul, 2014). A study reported by Daily Mail (2014) has showen that more than half of children have been a social media user before age 10 and 52 percent of eight to 16-year-olds do not obey the age limit of Facebook users.

In fact, Facebook addiction may become another addiction disorder after drugs and alcohol addiction (Das and Sahoo, 2011). It is a kind of Internet addiction that leads to sinking in a virtual life and forgets about the physical world around them. A survey of a thousand people across the United States to find people addicted to social media found that 56 percent of users check Facebook at least once a day and 29 percent could stay only a few hours without checking their accounts. The study says people under 25 years old are more likely to lose sleep time only to supervise their friends' post (Das and Sahoo, 2011). A study conducted by Nucleus Research on 237 corporate employees show that 77 percent of them use Facebook during work hours, causing a decrease in productivity of 1.5 percent of employees (Gaudin, 2009). Furthermore, the Daily Mail reported that crimes correlated with social media have increased by 7000 percent in some areas, including murder, rape, pedophilia, bullying, assault, and robbery (Das and Sahoo, 2011). The research center of University of New Hampshire say that the vast majority of cases involve young teens aged 13 to 15 years (Steenhuysen, 2008).

Besides negative impacts, the use of social media also has positive impacts. There are many schools and universities that are interested in social media such as blogs to improve or complement the activities of formal education and improve learning outcomes (Brennan, McFadden, and Law, 2001; Brennan, 2003; Notley, 2010). Social media are also used to expand opportunities for formal learning in the geographical context. Students use instant messaging and Skype to share information about their 
culture and work together (Collin et al., 2010). In addition, social networks can also be used between teachers and students to be able to improve the relationship and the motivation and engagement with education (Mazer, Murphy, and Simonds, 2007). Social networks are also important in informal learning as well as other necessity such as for online marketing, IT advancement and production of creative content, and methods of parenting for young parents (Notley, 2009).

Social media use by teenagers can be influenced by the family, environment, and individual characteristics of the teenager. Family is the first and principal environment that gives a lot of influences on various aspects of social development of children (Fatimah, 2006). As the closest environment, family through parenting greatly influences the level of child development and plays a role in monitoring the child's behavior including social media use behavior. Likewise, the influence of peers in the use of social media is also noteworthy. Peer influence on attitudes, speech, interests, appearance, and behavior outweigh the influence of family (Hurlock, 2009). Social media information obtained through peers can also influence the pattern of social media use.

In addition, many attractive features of social media also make teenagers tend to become addicted and lazy. It results in a lot of wasted time and activity that disturbed teenagers, such as their learning schedule, eating, sleeping, socializing, and so on. The amount of time spent to use social media leads to reduced learning time because teenagers are too tired to have fun in social networks, so the academic achievement of children in school can be disrupted.

This study was conducted to analyze the effect of social media use and parenting styles on motivation to learn and the academic achievement of teenagers. Therefore, the purposes of this study were: (1) to identify teenager characteristics, family characteristics, parenting styles, social media use, academic motivation, and academic achievement of teenagers in rural and urban areas of Bogor; (2) to analyze the correlation between parenting style, social media use, academic motivation and academic achievement of teenagers in rural and urban areas of Bogor; and (3) to analyze the effects of teenager characteristics, family characteristics, parenting styles, and social media use on academic motivation and academic achievement of teenagers in rural and urban areas of Bogor.

\section{Method}

\section{Participants}

This study used cross sectional design that was carried out in Bogor, West Java. The location of the study was four high schools selected by simple random sampling; two schools in Bogor Regency (representative of rural area) and two schools in Bogor City (representative of urban area). The samples were grade 11 students in the four schools which were taken by proportional random sampling as many as 120 students. 


\section{Measures}

Primary data was collected by using questionnaires, covering internal factors (age, gender, and pocket money), external factors (parental education, occupation of parents, parental income, and family size), social media use, parenting styles, and academic motivation. Secondary data were obtained from school records concerning a general description of the geographic school to support the facts on the field, data of students' enrollment and students' academic achievement.

Parenting style questionnaire was adopted from Hastuti, Sarwoprasodjo, and Alfiasari (2012). The questionnaire consisted of authoritarian parenting style $(\alpha=$ $0.622)$, authoritative parenting style $(\alpha=0.701)$, and permissive parenting style $(\alpha=$ $0.550)$ with 30 items rated on a 4 -point scale $(1=$ strongly disagree; $2=$ disagree; $3=$ agree; 4 = strongly agree). Academic motivation questionnaire was modified from Herniati (2011), consisting of 30 questions of the intrinsic and extrinsic academic motivations $(\alpha=0.853)$. The questionnaires used a 4-point Likert scale $(1=$ strongly disagree; 2 = disagree; 3 = agree; $4=$ strongly agree). The obtained score of parenting style and academic motivation were summed to create an index. The index value would be projected into three different categories: low $(<60)$, moderate $(60-80)$, and high $(>80)$.

Social media use was measured based on the following dimensions: motive, account ownership, frequency, duration, cost, and type of social media used. The motives of social media use in this study were measured by using six dimensions of motives of Facebook use (Sheldon, 2008): relationship maintenance, passing time, virtual community, companionship, coolness, and entertainment. The information sources to access social media that mostly influence the teenagers in this study were grouped into several reference groups: friends, parents, teachers, relatives, television, and the Internet.

The academic achievement of teenagers in this study is measured from the results of student grades, which are then classified into four categories according to Permendikbud (2013): poor ( $\leq 2.49$ ), fair (2.50-2.99), good (3.00-3.49), and excellent (3.50-4.00) (Decree of Minister of Education and Culture No. 81A/2013).

\section{Analysis}

The data was analyzed with descriptive analysis and inferential analysis. Descriptive analysis was used for all variables covering the internal factors, external factors, social media use, parenting styles, academic motivation, and academic achievement. Inferential analysis that was used covering Spearman correlation test to analyze the correlation between variables, independent sample T-test to analyze the difference between two groups, and multiple linear regression test to analyze the factors influencing academic motivation and academic achievement.

\section{Result}

\section{Teenager and Family Characteristics}

Most teenagers (84.2\%) were middle teenagers (age 15-17). More than half of teenagers $(57.5 \%)$ were girls and their pocket money $(70.8 \%)$ ranged from Rp15.000 to Rp30.000.000 per day. The length of education of their fathers (45\%) was more than 12 years, while the length of education of their mothers $(56.7 \%)$ ranged from 7 to 12 years. 
Most fathers (94.2\%) worked and more than half of the mothers $(62.5 \%)$ were a housewife. More than half of families $(55.8 \%)$ were classified in moderate family size. Most teenagers both in the rural (95\%) and urban (93.3\%) had income per capita above the poverty line of Bogor in 2011.

\section{Parenting Styles}

Parenting styles analyzed in this study were based on Baumrind's theory (2008) containing three parenting styles: authoritative, authoritarian, and permissive. Among those styles, parenting style carried out by most parents neither in the rural nor urban areas was authoritative parenting style $(95 \%)$, followed by authoritarian parenting style (4.2\%), and permissive parenting style $(0.8 \%)$. The results of independent sample T-test indicated that there was no significant difference between parenting styles in both areas ( $>>0.05)$.

\section{Social Media Use}

Among six dimensions of motive, the one mostly used by teenagers $(45.8 \%)$ was relationship maintenance. The existence of social media enables the teenagers to communicate easily and maintain ties with friends despite being in different places. Meanwhile, social media accounts owned by most teenagers were Facebook and Twitter. More than half of teenagers in the rural $(58.3 \%)$ and nearly half in the urban $(48.3 \%)$ had social media account as many as 3 to 5 accounts. The result of independent sample T-test indicated that there was a significant difference between the number of accounts owned by teenagers in the rural and in the urban $(p<0.05)$ in which urban teenagers had more accounts than rural teenagers.

The most influential source both in the rural (75.43\%) and in the urban (55.6\%) was friends. There was less than 10 percents of teenagers in both regions who knew social media accounts from their teachers. However, in this case the teacher provides the information about certain social media accounts which could be beneficial for the school duties such as blogs and Google+.

The average frequency of social media use was 1 to 3 times by one-third of teenagers in the rural $(33.83 \%)$ and in the urban $(36.2 \%)$. Meanwhile, the average duration of social media use was less than 60 minutes for one-time access by less than half of teenagers in the rural $(37.14 \%)$ and in the urban $(48.34 \%)$. In general, teenagers in the rural $(30.73 \%)$ and in the urban $(34.27 \%)$ accessed social media sites using the mobile phone. Most teenagers in the rural $(86.7 \%)$ and in the urban $(51.7 \%)$ spent relatively low cost to access social media per month $(<\mathrm{Rp} 102.700)$, while there were about 20 percent of teenagers in the urban spending relatively high cost (>Rp205.400). The results of independent sample T-test indicated that there were significant differences in the frequency, duration, and access cost of social media use of teenagers in both regions $(\mathrm{p}<0.05)$.

\section{Academic Motivation}

More than half of teenagers in rural and urban Bogor had a medium level of intrinsic and extrinsic academic motivations. Thus, more than half of teenagers in both areas $(79.2 \%)$ had the medium level of academic motivation in general. The result of independent sample T-test showed that there was no significant difference between 
academic motivations of teenagers in both areas, either intrinsic or extrinsic academic motivations.

\section{Academic Achievement}

Most of teenagers $(94.2 \%)$ in two regions had a good academic achievement with an average value of 3.19. The results of independent sample T-test showed that there was a significant difference between the academic achievement of teenagers in rural and urban $(\mathrm{p}<0.05)$ in which teenagers in urban area showed better academic achievement that that in rural area.

\section{Correlation between Parenting Style, Social media Use, Academic Motivation and Academic Achievement}

Table 1 shows that authoritarian and permissive parenting styles are negatively correlated with academic achievement of teenagers. It indicates that the higher the tendency of authoritarian or permissive parenting styles, the lower academic achievement will be. Furthermore, frequency, duration, ownership of the account, and access cost were positively correlated with academic achievement. The higher the frequency, the duration, the account ownership, and the costs to access social media, the higher the academic achievement will be.

Table 1 Correlation coefficient among parenting style, social media use, academic motivation and academic achievement

\begin{tabular}{lc}
\hline Variable & Academic achievement \\
\hline Authoritarian & $-0.272^{* *}$ \\
Authoritative & -0.119 \\
Permissive & $-0.187^{*}$ \\
Frequency (time/day) & $0.232^{*}$ \\
Duration (minute/one-time access) & $0.227^{*}$ \\
Account ownership & $0.296^{* *}$ \\
Access cost (IDR) & $0.190^{*}$ \\
Intrinsic motivation & 0.023 \\
Extrinsic motivation & 0.029 \\
Motivation & 0.032 \\
\hline
\end{tabular}

Note. $(*)$ significant at $\mathrm{p}<0.05 ;(* *)$ significant at $\mathrm{p}<0.01$

\section{Factors That Influence Academic Motivation}

The first multiple linear regression model shown in Table 2 explains 14.5 percent of the variables that significantly influence intrinsic academic motivation of teenagers while the rest $(85.5 \%)$ are influenced by other variables. Frequency and ownership of social media accounts would be potentially multikolinear, so it was not included in the regression tests. The results showed that intrinsic academic motivation of teenagers was influenced by authoritative parenting style, permissive parenting style, and duration of social media use. The increasing tendency of authoritative parenting style would raise an intrinsic academic motivation of teenagers by 0.400 point. Instead, the intrinsic academic motivation would decrease by 0.251 point due to the rising tendency of permissive parenting style. Meanwhile, the increasing duration of social media use would increase the intrinsic academic motivation of 1.037 point. 
Table 2 Factors that influence intrinsic academic motivation

\begin{tabular}{lccc}
\hline Variable & \multicolumn{2}{c}{ Intrinsic academic motivation } \\
\cline { 2 - 4 } & B & Beta & Sig. \\
\hline Region (0= rural, 1= urban) & 1.234 & 0.056 & 0.663 \\
Age (year) & 0.332 & 0.015 & 0.871 \\
Gender (0= girl, 1= boy) & -1.234 & -0.055 & 0.570 \\
Pocket money (IDR) & 0.000 & -0.164 & 0.154 \\
Father's length of education (year) & 0.235 & 0.063 & 0.549 \\
Mother's occupation (0= unemployed, 1= employed) & 1.686 & 0.074 & 0.425 \\
Family size (person) & -0.273 & -0.031 & 0.729 \\
Authoritarian (index score) & 0.182 & 0.151 & 0.120 \\
Authoritative (index score) & 0.400 & 0.317 & $0.004^{* *}$ \\
Permissive (index score) & -0.251 & -0.189 & $0.040^{* *}$ \\
Duration (minute/one-time access) & 1.037 & 0.211 & $0.033^{*}$ \\
Access cost (IDR) & $-1.249 \mathrm{E}-5$ & -0.090 & 0.392 \\
\hline $\mathrm{R}^{2}$ & & 0.231 & \\
Adj R & & 0.145 & \\
F & & 2.685 & \\
Sig. & & $0.003 \mathrm{a}$ & \\
\hline
\end{tabular}

Note. $(*)$ significant at $\mathrm{p}<0.05 ;(* *)$ significant at $\mathrm{p}<0.01$

Table 3 shows another multiple linear regression model which explains 8.1 percent of variables that significantly influence the extrinsic academic motivation of teenagers and the rest $(91.9 \%)$ are influenced by other variables excluded in this study. In this model, the factors that influenced the extrinsic academic motivation of teenagers were authoritarian parenting style, authoritative parenting style, and duration of social media use. The increasing tendency of authoritarian parenting style would raise the extrinsic academic motivation of teenagers by 0.207 point. The increasing tendency of authoritative parenting style would also raise the extrinsic academic motivation by 0.325 point. In addition, the increasing one minute of duration would increase the extrinsic academic motivation by 0.922 point.

Table 3 Factors that influence extrinsic academic motivation

\begin{tabular}{lccc}
\hline Variable & \multicolumn{2}{c}{ Extrinsic academic motivation } \\
\cline { 2 - 4 } & $\mathrm{B}$ & Beta & Sig. \\
\hline Region (0= rural, 1= urban) & 1.250 & 0.068 & 0.607 \\
Age (year) & -0.677 & -0.037 & 0.700 \\
Gender (0= girl, 1= boy) & -0.187 & -0.010 & 0.920 \\
Pocket money (IDR) & $-2.130 \mathrm{E}-5$ & -0.017 & 0.888 \\
Father's length of education (year) & 0.619 & 0.200 & 0.068 \\
Mother's occupation (0= unemployed, 1= employed) & 0.568 & 0.030 & 0.754 \\
Family size (person) & 1.070 & 0.148 & 0.116 \\
Authoritarian (index score) & 0.207 & 0.208 & $0.040^{*}$ \\
Authoritative (index score) & 0.325 & 0.310 & $0.007^{* *}$ \\
Permissive (index score) & 0.056 & 0.051 & 0.588 \\
Duration (minute/one-timeaccess) & 0.922 & 0.227 & $0.028^{*}$ \\
Access cost (IDR) & $-2.417 \mathrm{E}-5$ & -0.209 & 0.056 \\
\hline $\mathrm{R}^{2}$ & & 0.174 & \\
Adj R & & 0.081 & \\
F & & 1.880 & \\
Sig. & & $0.045 \mathrm{a}$ & \\
\hline
\end{tabular}

Note. $(*)$ significant at $\mathrm{p}<0.05 ;(* *)$ significant at $\mathrm{p}<0.01$ 


\section{Factors That Influence Academic Achievement}

The multiple linear regression model shown in Table 4 explains 27.7 percent of variables that significantly influence academic achievement of teenagers and the rest $(72.3 \%)$ are influenced by other variables. In this model, the factors that influenced the academic achievement of teenagers were region, gender, and authoritarian parenting style. Teenagers in the urban had better academic achievement than those in the urban area. The academic achievement of teenage girls was also proved to be better than that of teenage boys. Meanwhile, the increasing tendency of authoritarian parenting would lower academic achievement by 0.003 units.

Table 4 Factors that influence academic achievement

\begin{tabular}{lccc}
\hline Variable & \multicolumn{3}{c}{ Academic achievement } \\
\cline { 2 - 4 } & B & Beta & Sig. \\
\hline Region (0= rural, 1= urban) & 0.071 & 0.250 & $0.037^{*}$ \\
Age (year) & -0.006 & -0.021 & 0.808 \\
Gender (0= girl, 1= boy) & -0.070 & -0.245 & $0.007^{*}$ \\
Pocket money (IDR) & $-2.822 \mathrm{E}-8$ & -0.001 & 0.989 \\
Father's length of education (year) & 0.005 & 0.095 & 0.335 \\
Mother's occupation (0= unemployed, 1= employed) & 0.033 & 0.114 & 0.185 \\
Family size (person) & 0.009 & 0.077 & 0.360 \\
Authoritarian (index score) & -0.003 & -0.199 & $0.030^{*}$ \\
Authoritative (index score) & -0.001 & -0.062 & 0.560 \\
Permissive (index score) & -0.002 & -0.142 & 0.101 \\
Duration (minute/one-timeaccess) & 0.000 & -0.008 & 0.932 \\
Access cost (IDR) & $1.803 \mathrm{E}-7$ & 0.100 & 0.306 \\
Intrinsic academic motivation (index score) & 0.000 & 0.012 & 0.898 \\
Extrinsic academic motivation (index score) & 0.001 & 0.060 & 0.503 \\
\hline $\mathrm{R}^{2}$ & & 0.362 & \\
Adj R & & 0.277 & \\
F & & 4.257 & $0.000 \mathrm{a}$ \\
Sig. & &
\end{tabular}

Note. $(*)$ significant at $\mathrm{p}<0.05 ;(* *)$ significant at $\mathrm{p}<0.01$

\section{Discussion}

The Internet is the world's largest network connecting different computer networks with different types of computers worldwide. It becomes the initial effort to support social media through communication between computers. Social media becomes one of the medium that is used by many people, including teenagers. Social media is a tool that allows users to show themselves and to connect with others (Fahmi, 2011). The use of social media among young people is increasing, and this even leads to addiction. It is inseparable from the role of the family as the closest environment to teenagers. Undoubtedly, family environment has a profound influence on the growth and development of children, and child behavior. Family characteristic in this study is seen from several variables and there are differences between the characteristics of the families in the rural and in the urban area, among which are the length of parental education and family income. Teenagers' parents in the urban identified in this study had higher length of education and income compared to in the rural.

The social media use can be seen through the motive of use, frequency, duration, number of accounts owned, and the total costs incurred to access social media. The 
results showed that there was a difference between social media use of the teenagers in the rural and in the urban. Frequency, duration of use, and number of account of the teenagers in the urban was higher than in the rural. This is in line with Qomariyah's study (2009) which shows that the frequency and duration of Internet use of urban youth at home tended to be more frequent than those in other places such as cafes, schools or wifi area. Moreover, this can be due to urban youth that is exposed to information in social media use more easily than youth in the rural. Parents in the urban area provide more facilities to children for social media use as well as the provision of the wifi at house and the amount of pocket money given to children tends to be large which will be used to buy Internet credits.

The social media use cannot be separated from the source of the information obtained by teenagers about social media itself. This study showed that the biggest influence on providing information within social media sites to teenagers was friends. This is in line with Karyatiwinangun's study (2011) revealing that close friends might be affecting teenagers more than parents, including in term of networking use. Teenagers spend so much of their time with peers that the influence of peers on attitudes, interests, and behavior is greater than the influence of the family.

The results in this study showed that teenagers' motive in social media use is to maintain relationship with people. This is in accordance with the study conducted by Desraza (2010) showing that majority of teenagers use social media to maintain the relationship with friends who have often encountered. Students use Facebook to keep in togetherness, improve relations with people who have been forgotten and to keep in touch with people who are known (Dogruer, Ipek, and Ramadan, 2011).

Parenting strongly affects the level of child development in the achievement of success and failure in social relationship. Parenting styles are divided into three, namely authoritarian, authoritative, and permissive. Parents with authoritarian parenting style try to create, control, and evaluate children's behaviors and attitudes based on a set of absolute standards, the values of obedience, respect for authority, work, tradition, no mutual giving, and receiving in verbal communication. Authoritative parents try to guide their children rationally, oriented on the problems encountered, appreciate give and take communication, explain the rational reasons underlying for each request or discipline. However, sometimes they use power if necessary. Meanwhile, permissive parents try to accept and be positive toward impulses, desires, and behavior of their children, use few punishment, consult with children, give few household responsibilities, allow the children to regulate his own activities without control, try to achieve a certain goal by giving reasons without showing the power (Baumrind, 1972). Most of parents in this study had the highest tendency of authoritative among other parenting styles. Parents who apply the authoritative parenting style provide warmth and support their children so that it can motivate children to study harder.

Frequency and duration of social media use, number of account owned, and access cost had a significantly positive association with teenagers' academic motivation. It is suspected that the teenagers accessing social media is not merely for entertainment purposes, but also for getting more information especially regarding school. The study of Kirschner and Karpinski (2010) shows that the use of Facebook makes children become a procrastinator that results in chaotic school work. In addition, they become weak as well in managing time.

Authoritarian parenting style was negatively correlated with academic achievement. It is presumed that parents' demands, highly discipline, and rigid parent- 
children relationship cause pressure in children which in turn declines their school performance. Alfiasari, Latifah, and Wulandari (2011) said that the authoritarian parenting style was negatively correlated with teenagers' academic achievement. However, Herniati (2011) proved the opposite result because parents implemented a number of regulations or highly demands and discipline that teenagers would try to meet it by learning diligently to achieve good grade.

This study showed that permissive parenting style was negatively correlated with academic achievement. Alfiasari, Latifah, and Wulandari (2011) also reveal that permissive parenting style is positively correlated with teenagers' academic achievement. On the other hand, Seth and Ghormode (2013) suggest that authoritative parenting style is positively correlated with academic achievement. The increase of authoritative parenting style tendency will be followed by the increase of academic achievement. However, this study did not reveal any significant relationship between authoritative parenting styles and academic achievement.

The regression test results showed that the authoritative parenting style positively affected the intrinsic and extrinsic academic motivation. This finding support prior study of Boveja (1998) that the higher tendency of authoritative parenting style, the better children will learn. Rahmaisya (2011) also suggests that one of factors affecting achievement motivation is the authoritative parenting style. The results also showed that permissive parenting style negatively affected intrinsic academic motivation. Authoritarian parenting style had a negative effect on extrinsic academic motivation, indicating that the adolscents' academic motivation is their fear toward parents' demands punishment. Parenting style to encourage children' academic achievement is authoritarian that directs the children to the destination with parent's control and power (Irmawati, 2004).

Furthermore, duration of social media use positively influenced the intrinsic and extrinsic academic motivation. Children who are addicted to the Internet will get bored to study and the fictional world is the best place for them to vent their inner dissatisfaction and depression (Xiuqin et al., 2010). Once they are involved in a network game for one or two years, they gradually begin to neglect their studies, become alienated from the reality of human relationships, and completely isolate themselves from the outside world.

Factors that influenced academic achievement in this study were the study location/region, gender, and authoritarian parenting style. Teenagers in the urban had better performance compared to those in the rural. It is possible that family characteristics may affect teenagers' academic attainment, such as the high level of parental education and family income per capita. Indeed, parental education will affect the development of children's education (Gunarsa and Gunarsa, 2004). The higher the parents' education level, the greater their knowledge regarding the importance of education. Meanwhile, high income per capita will provide the family sufficient financial resources for instrumental needs (Srinovita, Hastuti, and Muflikhati, 2012).

The results indicated that teenage girls tended to have better academic achievement than teenage boys did. There were significant differences between gender and intelligence in which the score of women was higher than that of men (Kumar and Lal, 2006). Sonja et al. (2009) also proved that girls were more cooperative with school rules and more competent in performance as well as in academic tasks. Some studies have shown that women have higher aspirations and success in achieving the goals of their academic than men (Buchmann and Dalton, 2002; Cooper, 2009; Gil-Flores, 
Padilla-Carmona, and Suárez-Ortega, 2011; Rothon et al., 2011). Other study has shown that teenage girls tend to express aspirations of jobs higher than teenage boys do, and complete undergraduate education than men do (Trustty and Niles, 2004).

Authoritarian parenting style had a significantly negative effect on teenagers' academic achievement. Authoritarian parenting style may cause teenagers to feel pressured and depressed, so that they cannot study optimally. Lakshmi and Arora (2006) have previously proved that the academic success of teenagers was negatively related to parents' control in which psychologically and physically high parental control tended to produce children with low academic achievement. This study did not find any effect of academic motivation on teenagers' academic achievement. It is suspected that there are other factors excluded in this study which are more influential on academic achievement. Musthaq and Khan (2012) suggested that communication, learning facilities, and proper guidance positively affected students' academic achievement while family stress had a negative effect. Academic self-concept is another factor that has been discussed to predict academic achievement (Asril, 2011; Bacon, 2011; Ghazvini, 2011).

\section{Conclusion and Recommendation}

\section{Conlusion}

Parenting style mostly found in this study is authoritative, implying that parents tend to always control the children flexibly. The social media use of teenagers is relatively low. Intrinsic and extrinsic academic motivations of teenagers are in middle category while the academic achievement is relatively good. The higher the tendency of authoritarian or permissive parenting styles, the lower academic achievement will be. On the other hand, the higher the frequency, duration, number of account ownership, and costs to access social media, the higher the academic achievement will be. The increasing tendency of authoritative parenting style will raise both the intrinsic and extrinsic academic motivations. Authoritarian parenting style will increase the extrinsic academic motivation yet lower the academic achievement. On the other hand, permissive parenting style is proved to lower the intrinsic academic motivation.

\section{Recommendation}

Based on the results, parents should pay more attention to parenting style applied by providing more support to increase teenagers' academic motivation because it is found that authoritative parenting style is one of factors influencing the academic motivation. Parents are also expected to control the teenagers' activities more flexibly rather than strictly especially regarding the social media use. School is expected to implement the rules that may restrict the social media use at schools which is less beneficial for learning process. Future studies should expand the scope of samples so that the results can represent various circles of society and provide better analytical results. In addition, it is advisable to look at the content in social media sites and explore deeply on social media uses. The research model can only explain 27.7 percent of the factors that influence academic achievement. Therefore, further research is needed to involve other factors that might be able to affect the academic achievement. 


\section{Reference}

Alfiasari, Latifah, M., \& Wulandari, A. (2011). Pengasuhan otoriter berpotensi menurunkan kecerdasan sosial, self-esteem, dan prestasi akademik remaja [Authoritarian parenting potentially lower social intelligence, self-esteem and academic achievement of adolescents]. Jurnal Ilmu Keluarga dan Konsumen, 4(1), 46-56.

Asril. (2011). Faktor-faktor psikologis yang mempengaruhi prestasi belajar siswa SMA Hang Tuah 1 Jakarta [Psychological factors that affect student achievement at Hang Tuah 1 High School Jakarta] (Undergraduate thesis). Retrieved from http://repository.uinjkt.ac.id/dspace/bitstream/123456789/2953/1/ASRIL-FPS.PDF.

Bacon, L. S. C. (2011). Academic self-concept and academic achievement of African American students transitioning from urban to rural schools (Doctoral thesis). Retrieved from http://ir.uiowa.edu/cgi/viewcontent.cgi?article=2582\&context=etd.

Baumrind, D. (1972). An exploratory study of socialiazation effects on Black children: Some Black-White comparisons. Child Development, 43, 261-267.

Baumrind, D. (2008). Parental authority and its effect on children. Parenting for Moral Growth (The Council for Spiritual and Ethical Education Newsletter), 1(2).

Boveja, M. E. (1998). Parenting style and adolescents' learning strategies in the urban community. Journal of Multicultural Counseling and Development, 26(2), 110-119.

Brennan, R., McFadden, M. \& Law, E. (2001). All That Glitters Is Not Gold: Online Delivery of Education and Training. Adelaide, Australia: National Centre for Vocational Education Research.

Brennan, R. (2003). One Size Doesn't Fit All: Pedagogy in the Online Environment (Volume 1). Adelaide, Australia: National Centre for Vocational Education Research.

$\begin{array}{lllll}\text { Claudia, } & \text { B., } & \text { D } & \text { (2002). }\end{array}$ Interpersonal influences and educational aspirations in 12 countries: The importance of institutional context. Sociology of Education, 75(2), 99-122. doi: 10.2307/3090287.

Collin, P., Rahilly, K., Richardson, I., \& Third, A. (2010). The benefits of social networking $\quad$ services. Retrieved from http://researchrepository.murdoch.edu.au/11804/1/FINAL_The_Benefits_of_So cial_Networking_Services_Lit_Review.pdf

Cooper, M. (2009). Dreams deferred? The relationship between early and later postsecondary educational aspirations among racial ethnic groups. Educational Policy, 23, 615-50. doi: 10.1177/0895904807312467.

Daily Mail. (2014, November 19). More than half of children use social media by the age of 10: Facebook is most popular site that youngsters join. Retrieved from http://www.dailymail.co.uk/news/article-2552658/More-half-children-use-socialmedia-age-10-Facebook-popular-site-youngsters-join.html.

Das, B., \& Sahoo, J. S. (2011). Social networking sites-a critical analysis of its impact on personal and social life. International Journal of Business and Social Science, 2(14), 222-228. Retrieved from http://www.ijbssnet.com/journals/Vol._2_No._14\%3B_July_2011/25.pdf.

Desraza. (2010). Hubungan antara motif pengguna Facebook dan pemenuhan kebutuhan afiliasi pada remaja [The relationship between the motives of Facebook users and the affiliates needs fulfillment of adolescents] (Unpublished undergraduate 
thesis). Depok, Indonesia: University of Indonesia.

Dogruer, N., Ipek, M., \& Ramadan, E. (2011). What is the motivation for using Facebook?. Procedia Social and Behavioral Sciences, 15, 2642-2646.

Fahmi, A. B. (2011). Mencerna Situs Jejaring Sosial (Bagaimana Situs Jejaring Sosial Membantu Memahami Diri Sendiri dan Orang Lain) [Digesting Social Networking Sites (How Social Networking Sites Helps Understanding Self and Others)]. Jakarta, Indonesia: Gramedia.

Fatimah, E. (2006). Psikologi Perkembangan (Perkembangan Peserta Didik) [Developmental Psychology (Development of Students)]. Bandung, Indonesia: Pustaka Setia.

Gil-Flores, J, Padilla-Carmona, M., \& Suárez-Ortega, M. (2011). Influence of sex, educational attainment and family environment on the educational aspirations of secondary school students. Educational Review, 3(63), 345-363.

Gaudin, S. (2009). Study: 54\% of companies ban Facebook, Twitter at work. Retrieved from

http://www.computerworld.com/s/article/9139020/Study_54_of_companies_ban_Fa cebook_Twitter_at_work.

Ghazvini, S. D. (2011). Relationships between academic self-concept and academic performance in high school students. Procedia Social and Behavioral Sciences, 15(2011), 1034-1039. doi:10.1016/j.sbspro.2011.03.235.

Gunarsa, S. D., \& Gunarsa, Y. S. D. (2004). Psikologi Praktis: Anak, Remaja dan Keluarga [Practical Psychology: Children, Youth and Families] (7th ed.). Jakarta, Indonesia: Gunung Mulia.

Hastuti, D., Sarwoprasodjo, S., \& Alfiasari. (2012). Model Harmonisasi Peran Keluarga dan Sekolah dalam Pembentukan Karakter Mulia Remaja bagi Tercapainya Visi Insan Cerdas Komprehensif Tahun 2014 [Harmonization Model of Family and School Role in Noble Character Building of Youth to the Achievement of Comprehensive Human Intelligent Vision 2014]. Laporan Akhir Hibah Stranas Dikti.

Herniati, H. (2011). Gaya pengasuhan, konsep diri, motivasi belajar dan prestasi belajar siswa SMA pada berbagai model pembelajaran [Parenting style, selfconcept, motivation to learn and learning achievement of high school students at various learning models] (Unpublished undegraduate thesis). Bogor, Indonesia: Bogor Agricultural University.

Hurlock, E. B. (2009). Psikologi Perkembangan: Suatu Pendekatan Sepanjang Rentang Kehidupan [Developmental Psychology: A Life-Span Approach] (Istiwidayanti \& Doedjarwo, Trans.). Jakarta, Indonesia: Erlangga.

Irmawati. (2004). Prestasi dan pola pengasuhan pada suku bangsa batak toba di Desa Paepareran II Tapanuli Utara [Achievement and nurture at Toba Batak tribe in the village of North Tapanuli Paepareran II] (Undergraduate thesis). Sumatera Utara, Indonesia: University of North Sumatera.

Karyatiwinangun, F. (2011). Analisis hubungan pola penggunaan jejaring sosial dengan motivasi dan alokasi waktu belajar siswa SMP Negeri 1 Dramaga, Kabupaten Bogor [Analysis of the relationship patterns of social networking use with motivation and learning time allocation of student at 1 Junior High School Dramaga, Bogor] (Undergraduate thesis). Bogor, Indonesia: Bogor Agricultural University

Kirschner, P. A., \& Karpinski, A. C. (2010). Facebook and academic performance. Computers in Human Behavior, 26(6), 1237-1245. doi:10.1016/j.chb.2010.03.024. 
Kumar, R., \& Lal, R. (2006). The role of self- efficacy and gender difference among the adolescents. Journal of the Indian Academy of Applied Psychology, 32(3), 249-254.

Lakshmi, A. R., \& Arora, M. (2006). Perceived parental behaviour as related to student's academic school success and competence. Journal of the Indian Academy of Applied Psychology, 32(1), 47-52.

Mazer, J. P., Murphy, R. E., \& Simonds, C. J. (2007). I'll see you on "Facebook": The effects of computer-mediated teacher self-disclosure on student motivation, affective learning, and classroom climate. Communication Education, 56(1), 1-17. doi: 10.1080/03634520601009710.

Ministry of Communications and Information Technology. (2014). Pengguna internet di Indonesia capai 82 juta [Internet users in Indonesia to achieve 82 million]. Retrieved from https://kominfo.go.id/index.php/content/detail/3980/Kemkominfo\%3A+Pengguna+I nternet+di+Indonesia+Capai+82+Juta/0/berita_satker.

Ministry of Education and Culture. (2013). Peraturan Menteri Pendidikan dan Kebudayaan Republik Indonesia Nomor 81A Tahun 2013 tentang Implementasi Kurikulum [Decree of Minister of Education and Culture Number 81A 2013 of Curriculum Implementation]. Jakarta, Indonesia: Author.

Musthaq, I., \& Khan, S. N. (2012). Factors Affecting Students' Academic Performance. Global Journal of Management and Business Research, 12(9), 17-22. Retrieved from https://globaljournals.org/GJMBR_Volume12/3-Factors-Affecting-StudentsAcademic.pdf.

Notley, T. (2009). Young people, online networks \& social inclusion. Journal of Computer-Mediated Communication, 13(3), 1-31.

Qomariyah, A. N. (2009). Perilaku penggunaan internet pada kalangan remaja di perkotaan [Internet usage behavior of teenagers in urban areas]. Palimpsest : Jurnal Ilmu Informasi dan Perpustakaan, (1), 87-100.

Rahmaisya, R. (2011). Pengaruh persepsi gaya pengasuhan orangtua dan konsep diri terhadap motivasi berprestasi atlet muda di SMA Negeri Ragunan Jakarta [The influence of perceptions of parenting styles and self-concept on the achievement motivation of young athletes in Ragunan High School Jakarta]. (Undergraduate thesis). Retrieved from http://repository.ipb.ac.id/handle/123456789/47456.

Rothon, C., Arephin, M., Klineberg, E., Cattell, V., \& Stansfeld, S. (2011). Structural and socio-psychological influences on adolescents' educational aspirations and subsequent academic achievement. Social Psychology Education, 14(2), 209-231. doi: 10.1007/s11218-010-9140-0.

Saul, D. J. (2014). 3 million teens leave Facebook in 3 years: The 2014 Facebook demographic report. Retrieved from https://isl.co/2014/01/3-million-teens-leavefacebook-in-3-years-the-2014-facebook-demographic-report/.

Seth, M., \& Ghormode, K. (2013). The impact of authoritative parenting style on educational performance of learners at high school level. International Research Journal of Social Sciences, 2(10), 1-6.

Sheldon, P. (2008). The relationship between unwillingness-to-communicate and students' Facebook use. Journal of Media Psychology, 20(2), 67-75. doi: 10.1027/1864-1105.20.2.67.

Sonja, P., Milena, V. Z., Jana, K., \& Cirila, P. (2009). Students' social behaviour in relation to their academic achievement in primary and secondary school: Teacher's perspective. Psihologijske Teme, 18(1), 55-74. 
Srinovita, Y., Hastuti, D., \& Mufhlikhati, I. (2012). Pola asuh akademik, ketersedian stimulasi, dan prestasi akademik pada remaja dengan perbedaan latar belakang pendidikan prasekolah [Academic upbringing, the availability of stimulation, and academic achievement in adolescents with different preschool education backgrounds]. Jurnal Ilmu Keluarga dan Konsumen, 5(2), 147-156. Retrieved from http://journal.ipb.ac.id/index.php/jikk/article/view/6377.

Steenhuysen, J. (2008, February). Study rejects internet sex predator stereotype. Retrieved from http://www.reuters.com/article/idUSN1560642020080218.

Trustty, J., \& Niles, S. G. (2004). Realized potential or lost talent: High school variables and bachelor's degree completion. The Career Development Quarterly, 53(1), 2-15. doi: 10.1002/j.2161-0045.2004.tb00651.x.

Xiuqin, H., Huimin, Z., Mengchen, L., Jinan, W., Ying, Z., \& Ran, T. (2010). Mental health, personality, and parental rearing styles of adolescents with internet addiction disorder. Cyberpsychology, Behavior, and Social Networking, 13(4), 401-406. doi:10.1089=cyber.2009.0222. 